\title{
Tamed identities? Glimpsing her identity in Proverbs 10:1-22:16 and selected African proverbs
}

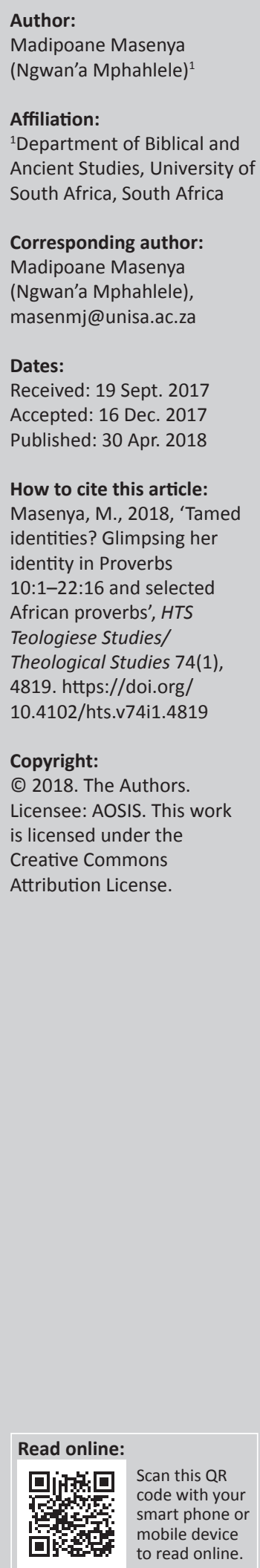

\begin{abstract}
Notions about worthy womanhood are shaped to a large extent by the cultural contexts in which they are constructed. In the global village though, shaped as it is mainly by Eurocentric cultures, it would be presumptuous to assume that one can with certainty pinpoint what may be termed 'purely traditional African notions of womanhood'. Also, it will be an exaggeration to argue that Africa does not have its own notions on ideal womanhood. Particularly in Christian African contexts, notions about womanhood are still shaped to a large extent by both the traditional African worldviews and the received biblical interpretations about womanhood. In the preceding scenario, one wonders if women's identities reveal their real selves or whether they are tamed, and thus artificial. In one's attempt to unravel notions of womanhood from both the corpus, Proverbs 10:1-22:16 and in the South African context (cf. selected African proverbs), this article has sought to answer the following main question: if images of women in selected African (Northern Sotho) proverbs (cf. also selected South African narratives) and in the book of Proverbs (cf. Pr 10:1-22:16) are brought together, what kind of picture may emerge from such a comparison?
\end{abstract}

\section{Introduction}

The topic on what constitutes worthy womanhood, a topic which may be deemed dated in other contexts, has arrested my attention since the early 1990s when I was first introduced to feminist and womanist literature. It continues to intrigue me even to this day. Especially informed by what happens in one's own context even today (cf. the examples provided in the following text), a context where African cultures and some conservative, apparently static interpretations of the Christian scriptures continue to hold power on what constitutes acceptable definitions of womanhood (read: tamed female identities), I continue to grapple with this question whose answer remains elusive. The main question asked in this article is the following: if images of women in selected African (Northern Sotho) proverbs (cf. also selected South African narratives) and in the book of Proverbs (cf. Pr 10:1-22:16) are brought together, which picture may emerge from such a comparison?

Informed by gender-conscious methodologies in which the experiences of women constitute a hermeneutical lens through which a biblical text is approached, as a point of departure, I offer examples which will hopefully reveal the complexity of definitions on (affirming) notions of womanhood in present-day South Africa.

\section{Glimpsing selected female narratives in the South African context}

Firstly, on 20-21 April 2016, I participated in a Seminar on Women in Academic Leadership, in Sandton, Johannesburg. One of the speakers, an academic at a South African university, highlighted the challenge which is faced by career women as they juggled their roles as homemakers and as career women in the public sphere. She exhorted her audience to keep a healthy balance between the two roles. An African proverb says: mosadi ke tšhwene o lewa mabogo $?^{1}$ A woman in the preceding culture should be industrious. In a nutshell, upon a career woman's arrival at home, the professor argued, she must cook for her husband, failing which marriages, especially between younger couples, would end up in divorce.

Viewed from an African gender-identified perspective, the exhortation by the female academic to career women to embark on traditional female chores upon arrival at home might be viewed with some distaste. While one does not recommend the disempowerment of interested women from household chores, the empowerment of husbands who choose to be house husbands should be 
encouraged (cf. Masenya [ngwan'a Mphahlele] 2004). Also, men who find themselves 'stuck' with household chores because of factors such as retirement and retrenchments, among others, should not be demeaned. The following questions are worth asking though: As some of the newly married men were involved with household chores in their fathers' households, why do they expect their career wives, who could even be more exhausted than themselves, to cook for them upon their return from work? Could it be a matter of lefotwana ge e se la gago, o hloba le gaela? ${ }^{2}$ The preceding questions may not make sense within individualistic, noncommunal and non-family-orientated cultures as it may be argued that a final decision on what would best serve a married woman's identity should be her own decision. One must however hasten to note that as a result of patriarchal pressure from within our African and global contexts among other factors, such a woman's independent and 'untamed' decision may not be an easy option. Even on the global scene dare one say, who in their right mind, whether male or female person or a member of the Lesbian, Gay, Bisexual, Transexual, Queer and Intersex (LGBTQI) persons, would wish to break their treasured relationship so easily? Who dares face the problematic repercussions of divorce not only on the couple involved but more importantly, on the children? Who has the courage and strength to marry and divorce indefinitely?

Secondly, a popular South African soapie titled 'Generations' (2016) featured a main female character by the name of Karabo Moroka. Karabo finds herself tossed between two male lovers, that is, a boyfriend named Zola and a husband named Tau. Zola appears to be Karabo's real soulmate while her husband, Tau, seems to be what may be designated a 'lover' of convenience. Faced with her predicament, Karabo then proposed polyandry as a solution to her dilemma, arguing that in the new South African democratic dispensation, a man is allowed to have more than one wife. In South Africa, a more visible example of polygamy is provided by the country's former chief executive leader, President Jacob Zuma. In a similar vein, argued Karabo, women should also be allowed to have more than one husband if they so choose. As could be expected in a culture which takes comfort not only in taming women, but also in defining what their real identities ought to be, Karabo's proposal for polyandry was met with vehement opposition from her two male lovers, her uncles and the children involved. Such a strong male resistance makes sense in a culture where tša etwa ke ye tshadi pele, di wela ka leope. ${ }^{3}$ Where in South Africa has the taboo of polyandry ever happened? If it is about to start, it cannot, or rather, it must never be a female initiative because it is bound to fail! Although Karabo's uncles and her two lovers eventually succumbed to her persistent request to marry the two men, heteropatriarchy continued to rear its ugly head within the context of the new union.

2.If a bird-ling is not yours, you remove its feathers even if it cries bitterly (Rakoma 1971).

3.If they (cattle) are led by a female one, they are bound to fall into a donga (Rakoma 1971)
The question that could be asked with Karabo in this regard is: In a so-called non-racist, non-sexist democratic context, why should a woman be barred from getting into a legitimate form of union such as polyandry?

Last but not least, 'I decided I would give it up to him rather than have him take it, a slightly more dignified option with the same effect' (Tutu van Furth as quoted by Bienne Huisman, City Press, 22 May 2016). The preceding words were reportedly said by the Reverend Canon Mpho Tutu van Furth, the daughter of Arch Bishop Emeritus, Desmond Tutu, who had married a Dutch female professor in December 2015. The words were said in the context of the pain Tutu van Furth had to endure of 'handing over' her ministerial credentials as a result of her marriage with a woman. Though the South African constitution legalised gay unions in 2006, the Anglican Church in South Africa recognises that marriage is a legitimate union between a man and a woman.

Yet Pressler (2006) would argue:

It (the sketch) does, however, challenge claims that there is a single biblical view of marriage, and highlights how little biblical basis there is for the view of marriage as a religiously sanctioned, unchanging institution defined by the private relationship between two individuals, one woman and one man to whom the woman must submit. (p. 206)

What may be concluded about the women (read: female selves) whose brief narratives were presented in the preceding examples? What may we make of the career woman who must maintain a healthy balance between her chores in the private sphere of the home and the public sphere of work? What about Karabo, a woman whose desire for polyandry is challenged by hetero-patriarchy and its beneficiaries? Which notions of womanhood emerge when a woman finds fulfilment both in her priestly calling and in her 'unconventional' marriage type? May we regard the preceding female identities as being tamed? Which picture may one get on notions of womanhood when one turns to selected texts from the intervening material in the corpus, Proverbs 10:1-22:16? To the preceding question we now turn.

\section{A virtuous woman, a divine gift}

A virtuous woman is a crown to her husband, but she who brings shame is as rottenness in his bones. (Pr 12:4; MEV)

Whoever finds a wife finds a good thing, and obtains favor of the Lord. (Pr 18:22; MEV)

Houses and riches are the inheritance of fathers, and a prudent wife is from the Lord. (Pr 19:14; MEV)

\section{A woman (wife), negatively portrayed}

A foolish son is the calamity of his father, and the contentions of a wife are a continual dripping of water. (Pr 19:13; MEV)

It is better to dwell in a corner of the housetop than with a brawling woman in a wide house. (Pr 21:9; MEV) 
The preceding texts from the corpus, Proverbs 10:1-22:16, that is, Proverbs 12:4; Proverbs 18:22; Proverbs 19:14; Proverbs 19:13 and Proverbs 21:9; MEV, will be engaged with in the present article, in one's continued search for affirming definitions of womanhood.

In the book of Proverbs, more than in any book of the Hebrew Bible, female imagery abounds. It was during the post-exilic period, in the absence of the monarchy and the Jerusalem temple, that the family regained significance as the locus of divine authority (Camp 1985). Does it occasion any surprise then that 'woman', particularly in her role as a husband's wife and as a household manager, would be given prominence in this book? The sages' main concern was thus on the building and maintenance of an honourable household, the well-being of women and men thus revolved on the well-being of their families, hence the sages' urge to a young man to find a good spouse (Yoder 2012:237).

An outsider to the biblical world and its conception of marriage (if any) might be surprised by the apparently neutral word used for woman in the preceding texts. The word, 'iššâ, which can be translated simply as 'woman', is used in the preceding texts to designate a married woman. Pressler (2006) thus appears to be on target when she reasons:

The Older Testament does not offer a single view of marriage, much less a single view of the family. Biblical Hebrew does not have a noun 'marriage' or a verb 'to marry'; it rarely uses terms that explicitly refer to marital status ('husband'4 or 'wife'; instead, the texts speak of a man 'taking' or 'having' a woman). (p. 202)

In specific Hebrew Bible texts, the textual context as well as intertextual readings will reveal whether the institution of marriage is in view or not. From the texts being investigated in this article and the context that is provided by the book of Proverbs, the family appears to form the framework within which these proverbs are written. Words such as 'fathers', 'heritage/inheritance', 'sons', 'man' ('išš or b'āal) and 'woman' ('iššâ) point in the preceding direction (Kittel $1967 ; 1977)$.

As in the Northern Sotho (African) language and culture, for example, it appears as though each mosadi ('iššâ) was expected to be a wife of a male person (cf. Masenya [ngwan'a Mphahlele] 2010). The proverbs such as lebitla la mosadi ke bogadi and mosadi ke tšhwene o lewa mabogo $0^{5}$ reveal the Northern Sotho's easy connection between mosadi ('iššâ or woman) and mohumagadi (a married woman or an 'ǐšša who is being taken by an 'iš). According to Fontaine, the key phrase, 'ěšet hayil, which opens Proverbs 31:10-31, is usually translated as: 'a capable', 'perfect' or 'good' wife, literally, 'a woman of worth' because the term for 'woman' and 'wife' is the same in

4.Though, continues Pressler (2006), "The terms ba'al [master -see Pr 12:4] and "ädö [lord] are used in the sense of "husband" slightly more frequently' (p. 202).

5.'The grave of a woman will be found at her husband's place' and 'A woman is a baboon, her hands are eaten', respectively.
Hebrew (1992:151). It thus appears that in ancient Israel (cf. also in African cultures), every Israelite adult woman ('î̌ššh) seems to have been expected to be married. Although the

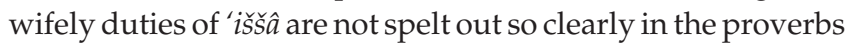
under investigation, few inferences can be made. In the immediate context of the corpus, Proverbs 10:1-22:16, it may not be far-fetched to argue that the very first text about a

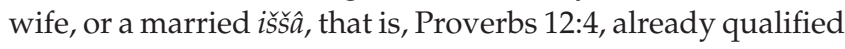
the nature of the wife who is desired: 'A virtuous woman is a crown to her husband, but she who brings shame is as rottenness in his bones' ([author's own italics]). The editor may thus have not deemed it necessary to keep on qualifying the nature of the wife who would be a good marriage candidate for the sons to consider. The words of Yoder (2012) are in order here:

Celebrated here for the first time in Proverbs, a 'woman of substance' (cf. 31:10-31) is said to promote her husband, whereas a 'shameful wife' destroys him like 'rot in the bones' (12:4). (p. 237)

Also, if the texts being discussed in this essay are read in the context of the whole book of Proverbs (cf. in particular the last chapter on the qualities of the 'ěšet hayil $\left.{ }^{6}\right)$, the reader will get a glimpse of the expectations that pre-exilic or post-exilic Israelite society had about women. ${ }^{7}$ Even in present-day Jewish contexts, argues Fox, when recited to a wife and mother (as in contemporary Jewish practice), the encomium expresses gratitude for a woman's achievements and contributions to the family (2009:905).

In a more or less similar vein, Brenner argues:

The virtuous wife who closes Proverbs is a paragon of virtue: no wonder that Jewish husbands still recite the poem to their wives today, either at their wedding or on Shabbath evening, according to their community's customs. (Brenner 2004:172; cf. also A. Braude, pers. Comm 1995; Brenner 1993; S. Gittay, pers. Comm 1995; H.E. Schaalmann, pers. Comm 1995)

However, one needs to problematise the applicability of the 'éšet hayil not only for contemporary (African) women Bible readers, but also for ordinary Israelite or Judahite women in the context of the paean's production. Why? In Proverbs 31:10-31, the sage presents an extraordinary (unrealistic?) portrait of an elitist woman who, on account of her socioeconomic class, could hire high-quality servants (cf. nearim). ${ }^{8}$

Many women, both then and now, may thus never match the socio-economic class of the 'éšet hayil.

An important question we ask at this point is: Which female identities feature in the preceding proverbial texts? Which notions of womanhood are revealed by the texts?

6.See a similar designation, that is, "ěset hayil, used in the opening text $(\operatorname{Pr} 12: 4)$ on texts about wives in the corpus, Proverbs 10:1-22:16.

7.'At any rate, during her lifetime, such a wife is convenient to have, since she has everything, apart from beauty (31:30)' (Brenner 2004:172).

8.Would it be far-fetched to speculate that though the 'eshet hayil' gets the honour for her industry, those who in fact did the spadework were her high-quality servant (naerim [31:15], Holladay 1971), in that sense, she becomes the (household) manager par excellence! 


\section{Notions of womanhood: Selected texts from Proverbs 10:1-22:16}

Firstly, as it is almost always the case in the Hebrew Bible, women do not get to talk about what their real identities are or should be, men usually talk about women. ${ }^{9}$

Secondly, talk about women reveals their significance and their preciousness in men's world then, and dare one say even today. Virtuous, prudent or wise wives could apparently not be picked up randomly because, 'Whoever finds a wife finds a good thing, and obtains favor of the Lord' (Pr 18:22 MEV; [author's own italics]).

An insertion of the word 'thing' after 'good' in English translations is noteworthy. I read the Masoretic Text (MT) (מצא אשה מצא טוב) (Kittel 1967; 1977) as follows: He who finds a woman/wife finds good. In my view, the MT's rendering which equates 'woman' with 'good' sounds more affirming to female readers than the one which is obtained in several English translations. How may one account for the translated (English) version which appears to objectify a female human being? Could it be that the insertion of the word 'thing' in the English translations ${ }^{10}$ is to be understood in a positive way, also in its poetic context? Or could it be problematised to entail that the androcentric translators could not bear the thought of a woman as representation of good? There is also an apparent contradiction between a male effort at finding an 'êšet hayil, and God (read: the Lord) who grants the favour. There appears to be a creative tension between the revelatory nature of the wisdom material (cf. God's involvement) and the great store set by wisdom literature on human (cf. human [male]) efforts at finding a wife. According to Yoder (2012), 'As women and minority groups have long insisted, different experiences yield different insights that can benefit the whole community. And wise people study them all' (p. 237). At the same time, the theological garment in which the proverbial material was coached by the later editors would entail God's involvement in the human (male) search for a wife.

Interestingly, in the first stichos, the nature of the wife is not stated. In the view of the sage, finding wives is synonymous to finding good. Such a man has obtained favour from God, ${ }^{11}$ the Giver of good gifts. The activity of the man, the subject, the seeker-husband-to-be, is contrasted with the passivity of the woman, the object to be found. Does it occasion any surprise then that those women, who, like Woman Stranger, might have been comfortable in reversing the preceding roles, would not have had any place in the ordered world of the sages?

\footnotetext{
9.Although Carol A. Newsom (1989) says the following words in the context of Proverbs 1-9, they can equally be applied to the proverbs under investigation in this essay: 'Consequently, it is significant that though woman is not the sole topic of the chapters, talk about women and women's speech occupies an astonishing amount of the text - men, preoccupied with speech, talking about women and women's speech' (p. 142).

10.MEV: 'Whoever finds a wife finds a good thing, and obtains favor of the Lord'.; KJV: 'Whoso findeth a wife findeth a good thing, and obtaineth favour of the LORD'; ASV: 'Whoso findeth a wife findeth a good thing, And obtaineth favor of Jehovah', GNB: 'Find a wife and you find a good thing; it shows that the LORD is good to you'.

11.In the context of Yehud, when the family had gained power as the locus of divine authority, it would make sense that finding a wife of substance would have been viewed as indeed tantamount to finding favour from the Lord.
}

Thirdly, and related to the preceding point, as the content of the proverbs depicts male talk about women, the perspective presented in these texts is also male (cf. Meyers 1988; 1992:245). Hence, the observation that the 'iššâ as she is reflected in these proverbs is always linked to her relationship with a (legitimate) male person as a heterosexual marriage partner. A good wife is also described as prudent (19:14). She is gracious and possesses honour as her gain (11:16). As already noted, such a wife is regarded as God's gift. Indeed, as the poet in Proverbs 31:10-31 would later argue about the 'éšet hayil, 'She will do him good and not evil all the days of her life' (Pr 31:12 KJV). Indeed, the 'êšet hayil as the tov [good], can only do her baal [husband], tov and not $r a^{\prime} y$ [evil], for as long as she lives. Fontaine (1992) is thus right when she reasons that the image of 'wife' as described in Proverbs reveals that the positive and negative roles of women are viewed basically from the viewpoint of what they provide for the men involved (pp. 145-152). The 'good' wife, that is, a 'woman of quality', is described as the crown of her husband (literally, 'master'). She brings him honour by elevating him, thus putting him on a pedestal. As already noted, her graciousness also enables her to retain honour (Pr 11:16).

Fourthly, the preceding positive qualities from a good wife are contrasted with those of the one 'who brings shame'. The latter wife degrades rather than enhances her husband's reputation (Pr 12:4). Her contentiousness, her revelling at quarrelling and her restlessness, are compared with a leaking roof, a continual dripping of rain: 'A foolish son is the calamity of his father, and the contentions of a wife are a continual dripping of water' (Pr 19:13 MEV). Just like a kēsîl, a foolish son who brings calamity to his father, is a quarrelling wife. Noteworthy is the fact that within the regular parental pair (cf. father and mother) visible in the corpus, Proverbs 10:1-22:16 (cf. Masenya 1989), only the father as a child's parent is mentioned in the preceding text. The mother (read: wife) is however not classified as a parent, but negatively along with a (foolish) child (read: son) in a synthetic parallelism. A contentious wife ${ }^{12}$ can only bring shame to the household. She cannot be tolerated by a husband who may rather find 'comfort' in unlikely places such as rooftops rather than share a (comfortable) house with a contentious woman.

As already noted, the words about women or female identities reach present-day readers through a man, one who may not necessarily do justice to the object of his discourse. The following questions are in order: If indeed the specific wife was contentious, what might have been the cause of such a trait? May her husband have been the main source of her contentiousness? What if what the sage presents as contentiousness is in fact female counsel? Claudia Camp (1985) reasons that:

12. The following Northern Sotho proverb is a fitting counterpart because it depicts the trait of quarrelsomeness or contentiousness as being typically female, mmetla the trait of quarelo metle wo motelele gobane kgadi le ka moše 'a noka a mmetla mpheng wa kgadi a betle wo motelele gobane kgadi le ka mose 'a noka e a lema. I can be literally translated as: 'the one who carves the handle of his sister's hoe must carve a long one because the sister hoes even across the river. The tenor of the preceding proverb alerts a boy with many sisters to anticipate the quarrels that would ensue once they get married. The implication is that the lesser the female siblings a male sibling has, the better position he would find himself in (Masenya [ngwan'a Mphahlele] 2004). 
All female figures in the book of Proverbs give advice of some sort, whether it is the nagging of the contentious wife, the seduction of the strange woman, the wisdom of the woman of worth or the truth and justice of personified Wisdom. (p. 90)

Fifthly, missing female identities and/or unusual silences on womanhood are notable in the texts under investigation (cf. also in the paean of the 'ěšet hayil in Pr 31:10-31). The sage's inclinations (attraction?) to female identities appear to have been based on women's capacity to possess the fear of the LORD, the fear that would have turned them into wise and good wives. The preceding emphasis makes perfect sense within the context of Wisdom Literature (cf. Pr 1:7). ${ }^{13}$ For present-day (female) readers of such texts, though, the texts' silence about a woman's physical appearance (read: beauty) may be found to be quite unusual, if not unattractive. In a more or less similar vein, in the paean of Proverbs 31: 10-31, we read, 'Charm is deceitful, and beauty is vain, but a woman who fears the LORD, she shall be praised' (Pr 31:30).

Related to the preceding observation is the relatively conspicuous absence ${ }^{14}$ of the positive portrayal of a woman as a sexual being, ${ }^{15}$ not only in the texts under investigation but also in the rest of the book. The sexuality of a woman features though in Proverbs' Instruction Literature, whether the latter was taught by a man (cf. Pr 1-9) or by a woman (cf. $\operatorname{Pr}$ 31:1-9). Wherever the topic on woman's sexuality occurs, it appears to be basically cast in negative words. A woman's sexuality (and beauty) must be viewed with suspicion as it is most likely to be used by women to break rather than make men, or so the sages thought (cf. Bird 1974:60). Gale Yee (1995) is thus rightly disturbed by the deeply unsettling message that the men communicate through the passages on Woman Stranger:

\begin{abstract}
... that only man pursues Wisdom like a lover, and it is a woman who seduces him away from her. How does one mitigate such imagery when it touches a person at the most elemental and symbolic level, for instance the sexual? (p. 126)
\end{abstract}

May it be that such negative portrayals of female sexuality or women as seductresses and adulterers are psychic portrayals (fantasies?) pointing to male weakness in controlling their strong sexual passions towards women? Even within the most overt text on female sexuality as positive (cf. Pr 5:15-19), one still finds traces of negative female sexuality as in, 'Should your fountains be dispersed abroad, streams of water in the streets?' (Pr 5:16).

13.The fear of the LORD is the beginning of knowledge; fools despise wisdom and instruction. The following proverb reveals the sage's apparent preference for inner rather than outer beauty, 'As a jewel of gold in a swine's snout, so is a fair woman who is without discretion' ( $\operatorname{Pr} 11: 16,22 \mathrm{MEV})$. Its Northern Sotho counterpart: $S e$ bone thola boreledi, teng ga yona go a baba: 'Do not be deceived by the outer appearance of a thola [a smooth red fruit], its inside is bitter'. Its tenor is, 'Outward (female) appearances can be deceptive' (Rakoma 1971).

14.In Proverbs 1-9, the beauty of 'woman' is depicted, albeit in a negative way. The sons (read: younger men) are exhorted to guard against the seductions of Woman Stranger, and whatever she stood for in the mind of the sage.

15.The only text in the Hebrew Bible that exhorts men (read: the young man) to monogamous sexuality is found in the book of Proverbs (cf. Pr 5:15-19). The young man is exhorted to drink water from his own cistern. He must delight in his own fountains only and rejoice in the wife of his youth.
The androcentricity of the text of Proverbs and its negative portrayal of female beauty and sexuality is revealed even from the rare instruction by a woman. According to King Lemuel's mother, Lemuel the son, needs to be careful about the objects which may destroy royalty; ironically, such objects are one of her own kind, the daughters of her womb.

What, my son? And what the son of my womb? And what, the son of my vows? Do not give your strength to women, nor your ways to that which destroys kings. (Pr 31:2-3)

So, a woman's womb has the capacity not only to produce the perpetuators of royalty, as in 'the son of her (read: my) womb' (Pr 31:2), the wombs can also produce those who are capable of destroying royalty, that is, the daughters of the wombs!

From the preceding examples, we might agree with Bird (1974) that the book of Proverbs as such (not excluding the corpus, Pr 10:1-22:16) portrays a wife in a more ambivalent light. Women as wives are depicted both positively and negatively.

\section{Conclusion}

In one's attempt to unravel notions of womanhood from both the corpus, Proverbs 10:1-22:16 and the South African context, this article has sought to answer the following main question: If images of women in selected African (Northern Sotho) proverbs (cf. also selected South African narratives) and in the book of Proverbs (cf. Pr 10:1-22:16) are brought together, which picture may emerge from such a comparison?

In patriarchal contexts like those engaged with in this essay, the power dynamics involved in the taming or un-taming of female identities need to be scrutinised and deconstructed in our search for that which might be found to be affirming and transformative by those on the margins. Notions of womanhood gleaned from both the African proverbs and the biblical ones highlight the role of a woman as a wife (cf. also Masenya [ngwan'a Mphahlele] 2007). As can be expected, the agenda of the proverbs gives readers a glimpse of the patriarchal contexts that produced them: a good wife's main duty is to do her husband good always. The desired wife's beauty is inward rather than outward. Such is a woman who knows her place within the patriarchal scheme of things, one created in the image of male persons (cf. the sages in the book of Proverbs and the male authors of African proverbs). On the other hand, the narratives that introduced this essay, basically presented unconventional notions of womanhood, thus revealing the complexities around definitions of womanhood in our day. The narratives introduce the readers to the black female selves whose desire is to be freed from the shackles of conventional traditional notions of womanhood within our (African) hetero-patriarchal contexts. Such women who dare to refuse to be tamed, thus refusing to be created in the image of men, many a time fall by the roadside. Eventually, it appears that the choice of what affirms one as a woman would depend on each individual woman's will to refuse to die as a copy of another human being. 


\section{Acknowledgements Competing interests}

The author declares that she has no financial or personal relationships which may have inappropriately influenced her in writing this article.

\section{References}

Bird, P.A., 1974, 'Images of woman in the book of proverbs', in R.R. Ruether (ed.) Religion and sexism: Images of woman in the Jewish and Christian traditions, pp. 41-60, Simon and Schuster, New York.

Braude, A., 1995, Personal Conversation, Evanton, IL.

Brenner, A., 2004, 'Proverbs', in D. Patte (ed.), Global bible commentary, pp. 163-174, Abingdon, Nashville, TN.

Brenner, A., 1985, The Israelite woman: Social role and literary type in biblical narrative, JSOT, New York.

Camp, C.V., 1985, Wisdom and the Feminine in the Book of Proverbs, JSOT, Sheffield.

Fontaine, C.R., 1992, 'Proverbs', in C.A. Newsom \& S.H. Ringe (eds.), The women's bible commentary, pp. 145-152, Westminster/John Knox, Louisville, KY.

Fox, M., 2009, Proverbs 10-31: The Anchor Yale Bible, A new translation with introduction and commentary, Yale University Press, New Haven, CT.

Gittay, S., 1995, Personal Communication, Port Elizabeth.

Holladay, W.L., 1971, A concise Hebrew and Aramaic Lexicon of the Old Testament, Brill, Leiden.

Kittel, R. (ed.), 1967/1977, Biblia Hebraica Stuttgartensia, Deutsche Biblestiftung, Stuttgart.
Masenya, M., 1989, 'In the school of wisdom: An interpretation of some Old Testament proverbs in a Northern Sotho context', Unpublished Master of Arts dissertation, University of South Africa, Pretoria, South Africa.

Masenya (ngwana' Mphahlele), M., 2004, How worthy is the woman of worth? Rereading Proverbs 31:10-31 in African-South Africa, Peter Lang, New York.

Masenya (ngwan'a Mphahlele), M., 2007, 'Seeking security through marriage: Ruth1:6-18 placed under an African woman's HIV and AIDS lens', Journal of Constructive Theology 13(2), 43-56.

Masenya (ngwan'a Mphahlele), M., 2010, 'Is Ruth the 'êšet hayil for real? An exploration of womanhood from African proverbs to the threshing floor (Ruth3:1-13)', Studia Historiae Ecclesiasticae XXXVI(Suppl), 253-272.

Meyers, C., 1988, Discovering eve: Ancient Israelite woman in context, Oxford University, New York.

Meyers, C., 1992, 'Everyday life: Women in the period of the Hebrew Bible', in C.A. Newsom \& S.H. Ringe (eds.), The women's Bible commentary, pp. 244-251, Westminster/John Knox, Louisville, KY.

Newsom, C.A., 1989, 'Woman and the discourse of patriarchal wisdom: A study of Proverbs 1-9', in P.L. Day (ed.), Gender and difference in ancient Israel, pp. 142-160, Fortress, Minneapolis, MN.

Pressler, C., 2006, 'The "biblical view" of marriage', in L. Day \& C. Pressler (eds.), An introduction to feminist biblical interpretation in Honor of Katharine Doob Sakenfeld: Engaging the Bible in a gendered world, pp. 200-211, Westminster John Knox, Louisville, KY.

Rakoma, J.R.D., 1971, Marema-ka-Dika tša Sesotho sa Leboa, van Schaik, Pretoria.

Schaalmann, R.E.,1995, Personal communication, Evanston, IL.

Yee, G.A., 1995, 'I have perfumed my bed with myrrh': The foreign woman ('ššâ zārâ) in Proverbs 1-9', in A. Brenner (ed.), A feminist companion to wisdom literature, pp. 110-130, Academic Press, Sheffield.

Yoder, C.R., 2012. 'Proverbs', in C.A. Newsom, S.H. Ringe \& J.E. Lapsley (eds.) Women's bible commentary (twentieth-anniversary edition: Revised and updated), pp. 232-242, Westminster John Knox, Louisville, KY. 